\title{
Intertextuality and Interdiscursivity in Facebook Users Comments on Kompas.com News Update under the Topic of Paris Tragedy
}

\author{
Ahmad Zulfahmi Muwafiq;; Sumarlam Sumarlam; Diah Kristina \\ Universitas Sebelas Maret, Indonesia \\ Email: elmi182@gmail.com
}

http://dx.doi.org/10.18415/ijmmu.v5i5.376

\begin{abstract}
This article explores how intertextuality and interdiscursivity in users comment on Facebook is exploited to supplement discrimination, repression or suppression to others. The Discourse Historical Approach (DHA) which falls under the umbrella of critical discourse analysis is employed to explore the mechanism of intertextuality and interdiscursivity in the users' comments responding to news updates under the topic of Paris Tragedy posted by Kompas.com on its fans page. The data which are collected from the users' comments are analyzed qualitatively. The finding shows that intertextually users import religious texts into their comments. The users also import discourses including discourse on religion, discourse on Middle East conflict, discourse on terrorism and discourse on law. In doing so, some texts and discourses undergo recontextualization by which certain elements of social practice are substituted or removed to serve the communicative purpose of the users' comments. Finally, intertextuallity and interdisursivity serve to build a stigma by which a certain religion is negatively presented; to give the sense of natural to the act of terrorism; to belittle the victims of the act of terrorism and to build negative evaluation through evocation of past events
\end{abstract}

Keywords: Discourse Historical Approach; Intertextuality; Interdiscursivity; Facebook Comments

\section{Introduction}

As information becomes highly accessible in the internet age, social media interaction has involved complex intertwining of texts and discourse. This complex interlocking text or discourse fosters the quality of the interaction flow. By exploiting intertextual and interdiscursive resources, users enrich their experience for information exchange. This consequentially benefits the main function of having interaction on social media, as Zappavigna (2012, p. 12) states, to enact relationship.

However, in the actual interaction the ideal condition happens not to be always in place. The actual interaction especially on Facebook, as suggested by Muwafiq, Sumarlam \& Kristina (2018), also involves violence (see also Simangungsong., 2016; Toni., 2017; Nasrullah., 2015). Whenever facing sensitive issues, users likely start polarizing. In a minute, users become irrational. In doing so, seemingly users intentionally or less intentionally evoke intertextual and interdiscursive resource to supplement 
discrimination, repression or suppression others users. This makes the social function of Facebook (and social media in general) fades away.

Several previous studies were conducted to explore the mechanism of intertextuality and interdiscursivity. El Naggar (2012) explores the mechanism of persuasion using the Discourse Historical Approach (DHA) framework in the speech of Muslim televangelists Hamza Yusuf. He found that intertextuality and interdiscursivity plays pivotal roles to invoke some discourses and in doing so dismiss the others. He also found that the speaker recontextualized religious terms and endowed them with new meanings. Trester and West (2013) explores how face-threatening act (FTAs) are avoided and facework is accomplished through intertextual links that allow conversation to take place online. They found that although there are norms and expectations on Facebook, users may differ in receipting of what are actually face threatening and are creative in navigating the possible FTAs. The former study which employs the Discourse Historical Approach (DHA) as proposed by Wodak (2001) falls under the umbrella of critical discourse analysis. However, this study concerns the media other than Facebook. The later takes setting on Facebook and gives thorough overview of the mechanism of intertextuality and interdiscursivity yet the study excludes critical analysis.

Another research on intertextuality worth mentioning is one conducted by Pulungan, Subroto, Tarjana \& Sumarlam (2010) who investigated type, function and discursive practice of intertextuality in Indonesian newspaper opinion articles. It is found that the type of intertextuality dominantly exploited is indirect quotation and functions to provide things in detail. Interestingly the study discovers the cultural theme underlying the finding. It suggests that direct quotation is exploited so as to make academic sense of the articles (Pulungan., Subroto., Tarjana \& Sumarlam., 2010., p. 150). Thus, this makes the articles sounds authoritative. Yet, the study did not take to account the critical analysis.

The aim of the present paper is to explore how intertextual and interdiscursive resources exploited by Facebook users serve to supplement repression, exploitation, discrimination or suppression in the context of commenting news updates on the topic of Paris tragedy.

Two key concepts are used as the framework of the discussion. The first one is intertextuality and interdiscursivity. The idea is that texts and utterances are shaped by prior texts that they are responding to and by the subsequent text that they anticipate. In other word, there are relations between one text and other texts which are external to it. As suggested by Fairclough (2003, p. 39), the actual elements of other texts is in presence and is incorporated within a text obviously or less obviously. This is also signed through invoking a topic, an event or a main actor.

In doing so, as Wodak (2009) states, some elements of a text are recontextualized into or decontextualized away from the prior context. This results that the de-contextualized or recontextualized elements respectively loses or acquires new meaning. Recontextualizing principles proposed by Leeuwen (2008) would be fruitful to be exerted in the analysis. As proposed by Leeuwen (2008, p. vii), aspects of social practice such as actor, action, setting and timing in the process of recontextualization may be excluded and transformed. Recontextualizaion may also add elements such as purpose and legitimation for the actions.

Interdicursivity, in other hand, is indicated by the linkage of a discourse to other discourse. This linkage is indicated by the presence of a discourse topic within another discourse topic. More elaborately, Fairclough (2003, p. 37) suggests that interdiscursive relation includes the relations between genres, discourses and styles. This is shown, for instance, by Fairclough (1996, p. 210) in the analysis of British advertising discourse which is a hybrid of partly advertising discourse and partly traditional public information discourse type. 
The second one is the Discourse Historical Approach (DHA). The concept is introduced by Wodak (e.g. see Reisigl and Wodak, 2001; Wodak in Meyer and Wodak (eds.), 2001). The DHA takes into account four levels of context: 1) text-internal; 2) the intertextual and interdiscursive relationship between discourses; 3) the extra-linguistic social level and (4) the broader sociopolitical and historical context. DHA takes account a detailed analysis of intertextuality by illustrating interdiscursive and intertextual relationship as overlapping or intersection between two or more discourses, discourse topic, genres and text (see Reisigl and Wodak., 2001, p. 39).

\section{Methodology}

The source of data of this study are Facebook users' comments responding to the news updates under the topic of Paris tragedy (November 13, 2015). The news updates were posted by Indonesian news portals namely Kompas.com from November 2015 to January 2016. As cited by Santosa (2014), Lincoln and Guba argue that a qualitative research needs particular criteria used to avoid any deviations. The criteria include: 1) the comments (and replies) responding Paris tragedy; 2) the comments contains repression, exploitation, discrimination or suppression; 3) the comments contains intertextuality and interdiscursivity. The selected comments were analyzed qualitatively by following the DHA framework as proposed by Reisigl and Wodak (see Reisigl and Wodak., 2001; Wodak in Meyer and Wodak (eds.), 2001; Reisigl and Wodak., 2017).

\section{Results and Discussion}

It is perhaps important at the outset to delineate the social and historical context of Paris Tragedy. Paris tragedy or known as Paris attacks was a series of coordinated terrorist attack which occurred on Friday, 13 November 2015 in Paris, France. The attack was perpetrated by ISIS/ISIL (Islamic State in Iraq and Syria/ Islamic State in Iraq and Leviathan), an Islamist paramilitary group occupying some part of Syria and Iraq land and seeking to restore the caliphate. ISIS is best known for the use of violence. This attack leads a massive response from the world. Afterward, Paris attack happened to be a Facebook trending topic. Most of the response were condemning the attack and showing support to Parisians. One of the popular yet cliché debate in the post $9 / 11$ era related to the attack was the relationship between terrorism and Islam. Under those of sociopolitical and historical contexts, Facebook users posted the comments. Some topics were colliding with other surrounding topics which represents the current sociopolitical inclination.

\section{Intertextuality}

Intertextuality by which texts are linked with other texts is signed by the presence of the actual elements of a text in another text. The users import fragmented piece of religious texts into their comment and make reference to it. The fragmented piece of religious text serves to legitimize stigma by which certain religions are negatively constructed.

As an example, below is a reply posted by a user intialed GM. This reply is posted to respond users who react to GM's comments on a news update under the title "Pemuda Muhammadiyah: Islam Korban Pembajakan Terorisme" (Pemuda Muhammadiyah: Islam is The Victim of Terrorist Hijack") (see Appendix 1). 


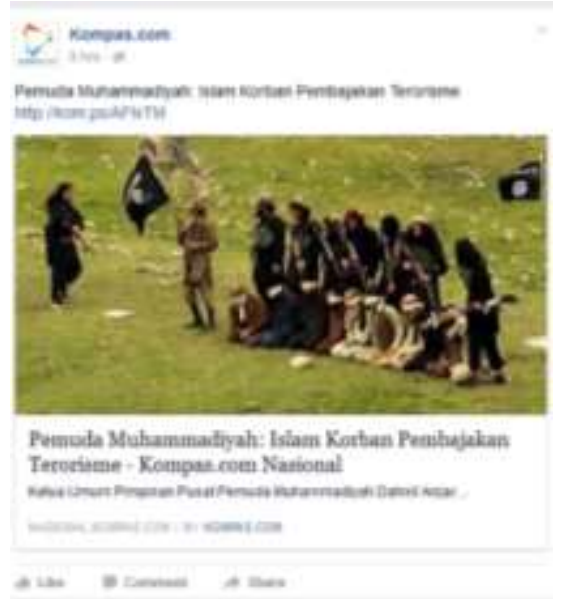

Fig. 1 News update from Kompas.com entitled "Pemuda Muhammadiyah: Islam Korban Pembajakan Terorisme"

It begins by GM whose response to the news consists negative evaluation to Islam. It is stated "Islam memang jahat. Ajarannya kacau balau" (Islam is evil and the teachings are chaotic). This provocative comment raises negative reactions from other users. Within this context of situation, the reply "Bunuh orang-orang kafir yang ada disekitarmu" (Kill disbelievers who are around you) as shown in the figure bellow is posted. Other than importing the text, GM also makes an explicit reference to the intertextual resource as shown by "QS 9: 123, QS 9:5" which refers to Quran Surah At Taubah (9) verse 123 and verse 5 .

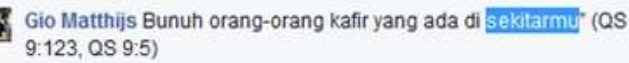

Fig. 2 A reply from GM

The fragmented piece of religious text brought by GM into his reply is originated from Quran Surah At Taubah (9) verse 123, "You who believe! Fight the disbelievers are near you and let them find you standing firm; be aware that God is with those who are mindful of Him" (Quran 9: 123, Oxford World's Classic Edition). In addition, GM mentioned "QS 9: 5" which refers the same surah verse 9 as presented below.

When the [four] forbidden moths are over, wherever you encounter the idolaters, kill them, seize them, besiege them, wait for them at every lookout post; but if they turn [to God], maintain the prayer, and pay the prescribed alms, let them go on their way for God is most forgiving and merciful (Quran 9: 5, Oxford World's Classic Edition)

This fragmented piece of text is brought into the reply so as to fulfill the communicative purpose of providing legitimation to GM fallacious argument that Islam is evil and the teachings are chaotic because it teaches killing. This constructs a stigma that Islam is closely associated with violence.

This text gains new meaning as the recontextualization occurs. The sentence "kill disbelievers who are around you" was moved out from its original context in the Quran which, as Shihab (2007, p. $610)$ suggests, historically tells about warfare situation. This means that only under warfare condition the 
rule to fight against unbelievers is applicable. Otherwise, the sentence "kill disbelievers around you" suggests as if this rule is unconditionally applicable.

Importing solely the fragmented piece of text means excluding the elements of social practice embedded within it. The rule as stated in the later sentence, "But if they turn [to God], maintain the prayer, and pay the prescribed alms, let them go on their way for God is most forgiving and merciful" which contains the exception aforementioned rule of fighting the disbelievers is omitted. In other words, decontextualization deletes or removes elements of the text i.e. the historical context and the co-text by which understandable interpretation is construed. In doing so, the fragmented piece of "QS 9: 123"is falsely interpreted to legitimize the argument. In line with is the fallacy in dictione by which, as Reisigl and Wodak states (2001, p. 72), a participant 'twists somebody words' in order to be able to refute the antagonist argument more easily.

Other than removing the context, the user also make a modification in which the illocutionary force of the utterance is strengthen. This is shown in the text by the word "bunuh" (kill) which connotatively bears more negative sense than the phrase "perangilah" (fight against) as alternatively suggested. In other words, recontextualization substituted the elements of social practice "perangilah" by the semiotic element "bunuh" so as to build negative representation of Islam.

As shown in the analysis, intertextual resource primarily exploited by the users within the context of debate. Users make use of intertextual resource to legitimize stigma by which a religion is negatively represented. To bring the voice in, users use direct quotation and reference in which the text being intertextualized is still external. Intertextuality functions to build the academic sense by bringing in the authoritative voice of religious text. Interestingly user also makes use of reference which bear traceability side. In line with this is Pulungan, Subroto, Tarjana \& Sumarlam (2010) who suggest that (direct) quotation exploited to glorify the academic sense in a text.

It should be noted that as well as the presence of intertextuality, the presence of the Quran text in the reply also signifies interdiscursivity i.e. religious discourse. As stated by Reisigl and Wodak (2017), with 'discourse' which primarily is conceived as topic-related (discourse on), religious discourse in this reply is established through the topic of (religious) rules of warfare. This is in the text is realized by the imperative sentence "Bunuh orang-orang kafir yang ada disekitarmu" (Kill those unbelievers who are around you).

\section{Interdiscursivity}

As stated earlier, interdiscursivity indicates that discourse are linked to each other through topic on other discourse (Reisigl and Wodak., 2009, p. 90). Users' comments on Paris Tragedy has many hybrid discourse which include discourse on Syria conflict, discourse on Charlie Hebdo attack, discourse on Iraq war, discourse on law, and discourse on the Crusade. These discourses reflect social and political background in the time when the comments were posted. This Interdiscursivity is established through reference to event and discourse topic. 


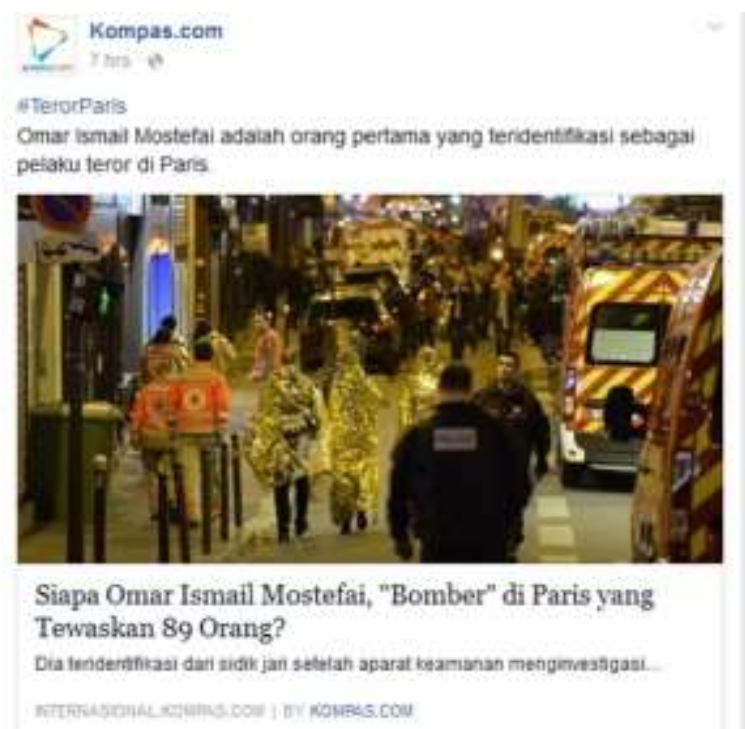

Fig. 3 News update from Kompas.com entitled "Siapakah Omar Ismail Mostefai, Bomber di Paris Yang Tewaskan 89 Orang?"

Below is the comment posted by a user initialed BD who responds to a news update (Figure 3) entitled "Siapakah Omar Ismail Mostefai, Bomber di Paris Yang Tewaskan 89 Orang?" (Who is Omar Ismail Mostefai, a Paris Bomber who Killed 89 People?). He provocatively states, "Bangsa Arab ga suka dgn bangsa eropa. Tapi bangsa arab senang mengungsi ke eropa" (Arabians do not like Europeans yet they seek refuge in European countries).

Brussely Daniya Banhsa Arab ga suka dng bangsa eropa. Tapi bangsa arab

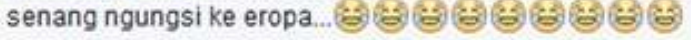
Like Reply - 6 hrs

Fig. 4 A comment from BD

Interdiscursivity is signed by the presence of discourse on Syria conflict. This is established through reference to the event of refuge as realized by the clause "Tapi bangsa arab senang mengungsi ke eropa" (yet they love to seek refuge in European countries).

To connect to the background of Syrian conflict, one should consider the historical context of civil war in Syria first. The civil war in Syria occurred during 2011 to 2016. The uprising was triggered by the widespread of the 'Arab Spring' which mobilized massive street protests (Muhammad., 2014, p. 10). Yet, the conflict roots deeply on the lack of freedom and economic woes. By the rise of rebel groups in 2013 aiming to overthrow the government, Syria began to slide into a civil war. The UN special envoy for Syria estimates 400.000 people were killed through past five years of civil war ("Aljazeera"., 2016). Many of them fled as refugee to neighboring countries including Lebanon, Iraq, Egypt and Jordan.

By reference to the event of refuge, BD tries to build negative self-representation of Arabs. They are negatively presented to be opportunists. As implied by the conjunction "yet", one who does not like another should not take his/ her aid. In other hand, Arabs who do not like Europeans love to flee to European countries as refugee. This shows nothing but negative evaluation of the attitude of Arabian people. 
Interestingly this self-negative representation also hides the fact that many Arabs seek refuge to European countries because the neighboring peninsula countries close their border ("CNN Indonesia", 2015). In other word, the user recontextualizes discourse on Syrian conflict about refugee by excluding certain elements of social practice, that Arabs seek refuge in European country for the neighboring peninsula countries closes their border, embedded within the discourse. This recontextualization serves the specific communicative purpose to build self-negative construction of Arab people.

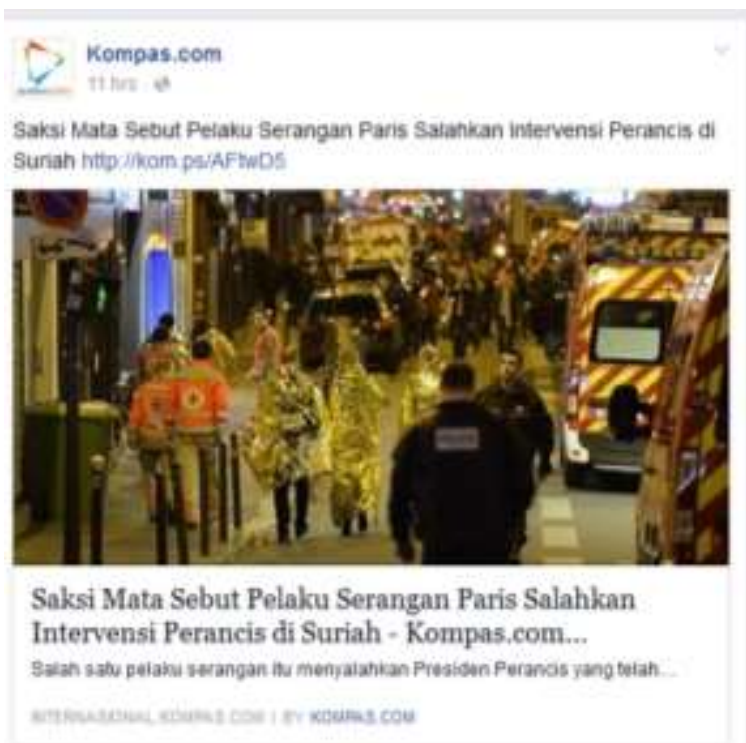

Fig. 5 News update from Kompas.com entitled "Saksi Mata Sebut Pelaku Serangan Paris Salahkan Intervensi Perancis di Suriah"

Users also import discourse on Charlie Hebdo into their comment to respond the news update on Paris tragedy. For example, the comment is posted by a user initialed DRAH who responds to news update entitled "Saksi Mata Sebut Pelaku Serangan Paris Salahkan Intervensi Perancis di Suriah" (Witness Said That the Attackers Blames France for The Act of Military Intervention in Syria) (Fig. 5). DRAH states as follows.

Denny Rieka Asyifatu Haifa Mantap lah.

Prancis membuat undang2 larangan berhijab...

Dulu karikatur prancis membuat komik yg menjelekan nabi muhammad. Ini hasilnya, ayo negara mana lagi yg menghina.

Fig. 6 A comment from DRAH

Mantaplah. Paris membuat undang-undang larangan berhijab. Dulu karikatur Prancis membuat komik yang menjelekkan nabi Muhammad. Ini hasilnya. Ayo negara mana lagi yang menghina?

Well done! Paris has made a law about the ban of wearing hijab (headscarf). Also, France caricaturist had made a comic which insulted Prophet Muhammad. This is the result. Come on! Is there else any country which want to do so? 
Interdiscursive relationship to discourse on Charlie Hebdo is established through reference to the topic about Muhammad cartoons. This is realized by the noun phrase "komik yang menjelekkan nabi Muhammad" (a comic which insulted Prophet Muhammad).

Charlie Hebdo is satirical weekly magazine which features cartoons, reports, polemics and jokes. It is known for being controversially irreverent and stridently non-conformist tone depicting public figures including religious figures. In 2014, Charlie Hebdo provocatively published a cartoon depicting Muhammad being slaughtered by ISIS ("Tempo"., 2015). This evoked massive reactions from Muslims. Unfortunately, on January, 2015 the attack by allegedly Islamist group on Charlie Hebdo office resulted 12 casualties ("BBC”., 2013).

Discourse on Charlie Hebdo is imported by the user into the comment to legitimize ISIS' attack in Paris. This serves to naturalize the deadly attack as if it is an unavoidable result for insulting Islam and depicting Prophet Muhammad. Discourse on Charlie Hebdo attack also serves to legitimize positive evaluation to the act of terror conducted by ISIS. This is realized by the sentence "mantaplah!" (Well done).

Discourse on Charlie Hebdo is interwoven with discourse on France law. This is established through reference to topic on France law about ban on Muslims religious attribute. The discourse is realized by the noun phrase "undang-undang larangan berhijab" (a law about the ban of wearing hijab) which refers to prohibition of the act of concealment of the face in public space.

The prohibition of the concealment act of the face in public space is not particularly addressed to Muslims group. Addressing the whole Parisians, the government prohibits any garments which conceal face including masks, helmets, niqab, burqa and balaclavas. Arguments supporting this includes gender equality and homeland security ("The Guardian"., 2018).

Discourse on France law as well as discourse on Charlie Hebdo serves to legitimate and naturalize ISIS attack on Paris tragedy. Both discourses build strong assumption regarding ISIS deadly attack which caused 130 casualties that it was as an unavoidable consequence of the media insulting Prophet Muhammad and the government banning Muslims.

By putting the discourse in, the user also recontextualizes it. The elements of social practice in discourse on France law is substituted by another semiotic elements. This is manifested in the text by the verb "berhijab" (wearing headscarf) which grammatically functions as modifier of "larangan" (ban). The original elements i.e. any garments covering face or full body including masks, helmets, niqab, burqa and balaclavas are prohibited to be worn in public area. These elements are substituted by the verb "berhijab" (wearing headscarf) which consequently reduces the discourse actual meaning.

Users also incorporate discourse on Iraq war and the Crusades. This for example is shown by the same user, DRAH, who replies a user initialed FB responding DRAH comment above. It begins with FB replies DRAH by saying, "Mas berarti emang bener sedikit disindir dan dikritik emosi? Bunuh orang? Aneh banget ajaran keyakinannya lol" (So, is it true whenever they are criticized, they get emotional? They kill people? This religious teaching is so weird. LOL.). Within this context, the reply bellow was posted (see Appendix 2).

Denny Rieka Asyifatu Haifa FA \# apa bedanya dengan agama lo yg

membunuh ribuan orang. Perang salib, di irak....hahaha....itu yg agama yg Iol, bunuh orang dari balita sampai manula

Like Reply 10 hrs

Fig. 7 A reply from DRAH 
It is said, "FA\# apa bedanya dengan agama lo yang membunuh ribuan orang. Perang salib, di Irak... hahha...itu yang agama yang lol, bunuh orang dari balita sampai manula" (FA\#, what is so different with your religion which killed thousands of people. The crusade, in Iraq. Hahaha. This religion is so lol. It killed all people, from the babies to the old one).

The interdiscursive relationship with discourse on Iraq war is established through reference to the place in which Iraq war happened. This is realized by the prepositional phrase "di Irak" (in Iraq). Iraq war refers to America invasion of Iraq in March 2003 to topple the Saddam regime. Argument supporting this includes possession of chemical weapon and human right violation (Erawan., 2007, p. 11). It is also stated that Saddam had a direct relationship with Al Qaeda, a militant Islamist group which was allegedly responsible for the $9 / 11$ attack in 2001. This military invasion resulted more than 450.000 civilian casualties (“BBC”., 2013).

Discourse on Iraq war is intertwined with discourse on the Crusade. The discourse on crusade is established through explicit reference to the topic of the crusade. This is realized in the text as noun phrase "perang salib" (the crusade). This refers to 200 years of war between Arabian Muslims empires and European Christian empires. It begun in 1095 and lasted in 1291 (Hillenbrand., 2000, p. 27). The purpose of this war was a political domination in the Middle East through conquering the holy land of Jerusalem. When the crusaders reached the city of Jerusalem, they randomly killed 70.000 civilians regardless their religion (Alkhateeb., 2016, p. 138).

Discourse on Iraq war as well as discourse on the Crusade serves to belittle the act of terrorism in Paris attack by comparing it with them in term of the casualties. In other words, relatively 'small number' of victims in Paris attack is nothing significant compared with thousands of them in both previously Iraq war and the Crusades. Additionally, both discourse are imported to legitimize a stigma to Christian which is assumed by DRAH to be the social actor of the Iraq war and the Crusades. This is signed in the text by the noun phrase "agama lo" (your religion). The phrase refers to FB's religion which is falsely presumed to be a Christian-also implied from the historical context that the Crusades involve Muslims against Christians.

To import both discourse into the reply, recontextualization has taken place by removing some short of the elements of social practices. Iraq war and the crusade by all means are different in term of the social actors. While the Crusades involved European Christian empires against Arabian Muslims empires, Iraq war involved secular Iraq government against US governments. To put the blame to the same social actor, which is "agama lu" (your religion) which refers to Christian would be over generalization. Thus, recontextualization removes the element of social actor by over generalizing. Argumentatively this is in line with secundum quid (over generalization fallacy), as Reisigl and Wodak (2001, p. 75) states.

Users' comments on Facebook responding to the news updates on the topic of Paris tragedy is indeed a 'cocktail' of discourse. They are full of interlocking images of texts and discourses which reflect the current social, political and historical context at the time the comments were posted. Yet, this complex mix of discourse which construe the users comment can be simplified mainly into four major types of discourse. These include discourse on Middle East conflicts which comprises discourse topic on Syria conflict, discourse topic on Iraq war and discourse topic on the Crusade; discourse on law which comprises the law of the act of concealment; discourse on religion which is in the text signed by the presence of the actual element of religious text about warfare situation; and discourse on terrorism. This is shown in the figure below. 


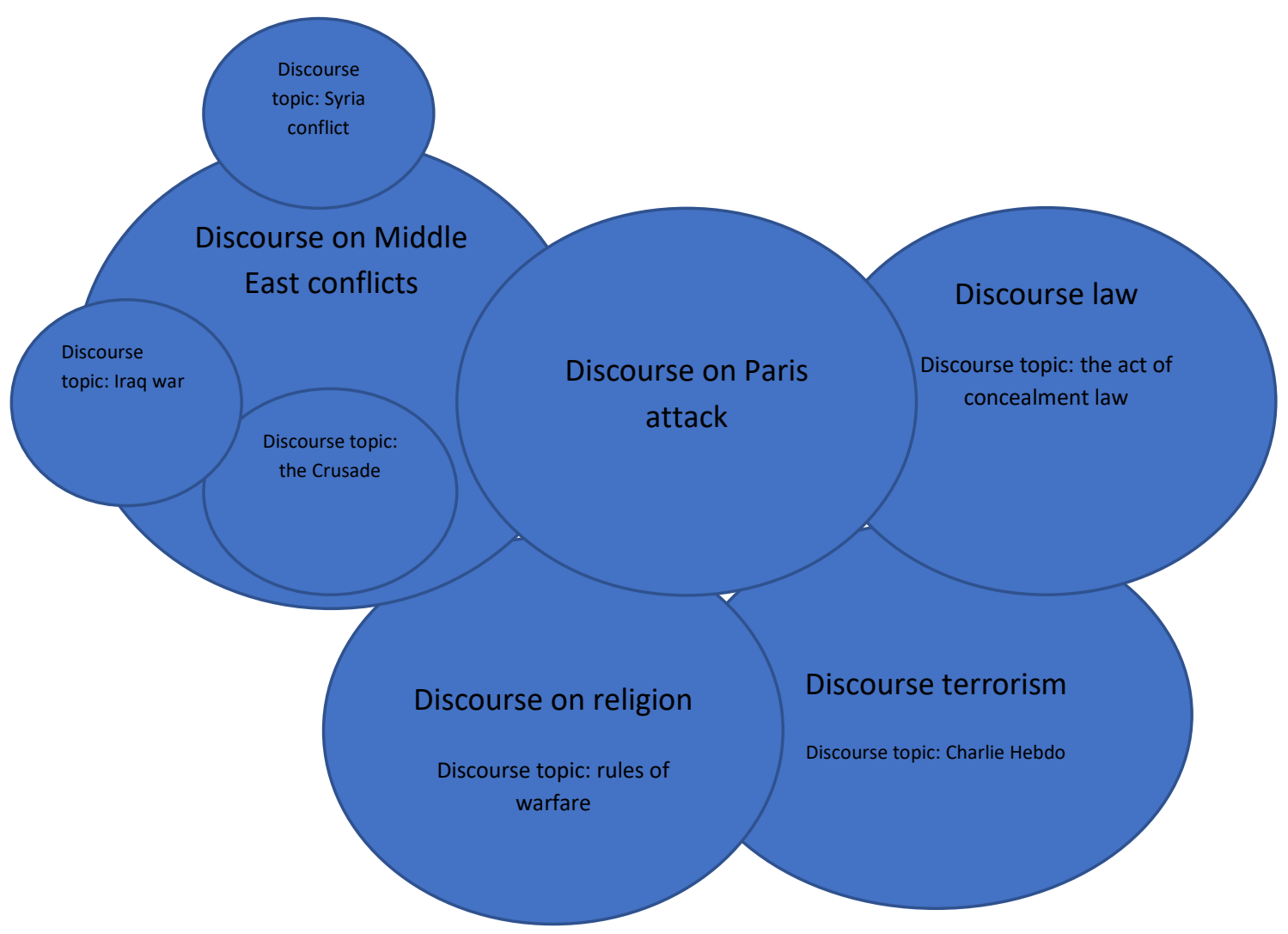

Fig. 8 Overlapping discourses in the users comments

\section{Conclusion}

To sum up, this study shows that the comments of Facebook users responding to the news updates posted by Kompas.com on the topic of Paris tragedy are actually a 'cocktail' of text and discourse. They are a very complex mix of texts and discourses which reflect the current social, political and historical context at the time the comments were posted. The users make use of intertextual and interdiscursive sources to serve legitimizing stigma and constructing self-negative image of religions and others. Additionally, users more or less intentionally make use of recontextualization to suit the imported discourses with that communicative purposes.

Intertextuality in the users' comments is established through the presence of the actual elements of the religious text. This intertextuality serves to provide legitimation for the user fallacious arguments by glorifying the sense of academic in the comments or replies. For example, as previously mentioned, the user imports the actual element of At Taubah verse 123 as well as making reference to the verses (Quran Surah 9 verse 5 and 123) which shares the thematic contents. The purpose is to legitimate the fallacious argument supporting the stigma that Islam teaches killing.

Interdiscursivity in the users' comment responding to the news update is established through reference to topics and events. The users invoke overlapping topics in many domains. For example, the user import discourse on Syria conflict (generally discourse on Middle East conflicts) which is established in the text as reference to the event of refuge wave of Arabs to European countries. Users also make use 
of discourse on law which is in the text established by reference to the event of 'hijab baning' (the act of concealment law). Additionally, discourse on terrorism is established through reference to Prophet Muhammad cartoon and discourse on religion is established through the rule of warfare.

Intertextual and interdiscursive resources in the users' comments undergoes the process of recontextualization by which the imported texts and discourses are suited to the communicative purpose. The texts as well as the discourse are modified by deletion and substitution of the elements of social practice within which the discourses are embedded. As previously shown, for example, the user imported Quran Surah 9 verse 123 that encourages offensive act of killing the unbelievers. Recontextualization excludes (deletes) the embedded elements of social practice which contextualize and specify the meaning of aforementioned verse 123.

Intertextual and interdiscursive resources are exploited by the users to achieve a certain communicative purpose i.e. to build and legitimize discrimination, suppression and repression to others. Intertextual resource exploited by the users serves to legitimize the arguments which supports a stigma by which certain religion is negatively presented. Interdiscursive source exploited by the user, in other hand, serves to give the sense of natural to the act of terrorism, to belittle the victims of terrorist act and to build negative evaluation through evocation of past events.

\section{Reference}

Alkhateeb, F. (2015). Sejarah Islam yang Hilang Menelusuri Kejaan Muslim Pada Masa Lalu. Bandung: Mizan.

El Naggar, S. (2012). Intertextuality and Interdiscursivity in the Discourse of Muslim Televangelists: The Case Study of Hamza Yusuf. Critical Approaches to Discourse Analysis across Disciplines, 6(1): 76-96.

Erawan, I. (2007). Perang Irak Kisah Pertempuran Garda Republik Melawan Agresi Militer Amerika Serikat. Yogyakarta: Narasi.

Fairclough, N. (1996). Language and Power. New York: Longman Inc.

Fairclough, N. (2003). Analysing Discourse: Textual Analysis for Social Research. London: Routledge.

Hillenbrand, C. (2015). Perang Salib: Sudut Pandang Islam. Jakarta: Serambi Ilmu Semesta.

Iraq Studies Estimates War-Related Death at 461,000. (2013, October 16). BBC. Retrieved from http://www.bbc.com/news/world-middle-east-24547256.

Kartun Charlie Hebdo Yang Kontroversial. (2015, January 8). Tempo. Retrieved from http://m.tempo.com/read/news/2015/01/08/117633512/10-kartun-charlie-hebdo-yang-kontroversial-1.

Leeuwen, T. V. (2008). Discourse and Practice New Tools for Critical Discourse Analysis. Oxford: Oxford University Press.

Simangunsong, B. A. (2016). Interaksi Antarmanusia Melalui Media Sosial Facebook Mengenai Topik Keagamaan. Jurnal ASPIKOM-Jurnal Ilmu Komunikasi,3(1): 65-76. http://dx.doi.org/10.24329 /aspikom.v3i1.99. 
Nasrullah, R. (2015). Perundungan Siber (Cyber-Bullying) Di Status Facebook Divisi Humas Mabes Polri. Jurnal Sosioteknologi, 14(1): 1-11. Oktaviani. http://dx.doi.org/10.5614\%2Fsostek.itbj.2015. 14.1.1.

Toni, A. (2017). Studi Netnografi “Komunitas Anti Islam'di Media Online Facebook. Prosiding SNaPP: Sosial, Ekonomi dan Humaniora, 7(1): 127-138.

Reisigl, M. \& Wodak, R. (2001). Discourse and Discrimination Rhetoric of Racism and Antisemitism. London: Routledge.

Reisigl, M. \& Wodak, R. (2017). The Discourse Historical Approach (DHA) [PDF file]. Retrieved from https://www.researchgate.net/publication/251636976_The_Discourse-Historical_Approach_DHA.

Shihab, M. Q. (2007). "Membumikan" Al-Quran: fungsi dan peran wahyu dalam kehidupan masyarakat. Bandung: Mizan Pustaka.

Muhammad, R. (2014). ISIS: Mengungkapk Fakta Terorisme Berlabel Islam. Jakarta: Noura Book Publsihing.

Muwafiq, A. Z., Sumarlam, S. \& Kristina, D. (2018). Discursive Strategies of Verbal Violence in the Users Comment on Facebook News Updates. Manuscript submitted for publication.

Pulungan, A., Subroto, E., Tarjana, S., \& Sumarlam, S. (2015). Intertextuality in Indonesian Newspaper Opinion Articles on Education: Its Types, Functions, and Discursive Practice. TEFLIN Journal, 21(2): 137-152. doi:http://dx.doi.org/10.15639/teflinjournal.v21i2/137-152.

Samosir, H. A. (2015, September 9). Kala Timur Tengah Membendung Gelombang Pengungsi. CNN Indonesia. Retrieved from https://www.cnnindonesia.com/internasional/20150908191154-12077454/kala-timur-tengah-membendung-gelombang-pengungsi.

Santosa, R. (2014). Metode Penelitian Bahasa. Unpublished manuscript.

Syria Death Toll: UN Envoy Estimated 400,000 Killed. (2016, April 24). AlJazeera. Retrieved from http://www.aljazeera.com/news/2016/04/staffan-de-mistura-400000-killed-syria-civil-war-

160423055735629.html.

Weaver, M. (2018, May 31). Burqa Bans, Headscarves and Veils: A Timeline Legislation in West. The Guardian. Retrieved from https://www.theguardian.com/world/2017/mar/14/headscarves-and-muslimveil-ban-debate-timeline.

West L. \& Trester, A. M. (2013). Facework on Facebook Conversation on Social Media. In Tanned, D. \& Trester, A. M. (Eds.). Discourse 0.2 Language and New Media. Georgetown: Georgetown University Press.

Wodak, R. (2001). The discourse-historical Approach. In M. Meyer \& R. Wodak (Eds.), Method of Critical Discourse Analysis (p. 63-94). London: Sage Publication Inc. 


\section{Appendix 1. Screenshot of GM interaction with other participants}

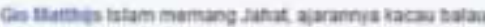

Cun Rugh ation

A Hoses fouplin

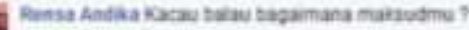

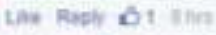

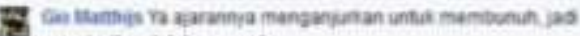
merava in acalah samcah

Like-Reply-B2-8 hrs

7. Amir Kuro islam itu baik, yang "kacau balau" itu hanya segelintir orang yg memperkosa ajarannya

Like Reply 15 - 8 hrs

Wahyu Arif Susilo kamu adja yang gk bisa bedain islam atw berkedok islam,low koment mending lu cari lebih rinci dlu.

Like - Reply - 3 - 8 hrs

20. Eidorian Prayoga sejak kapan ajaran kami mengajarkan membunuh...? kalau anda tidak tau tentang ajaran kami lebih baik anda diam, jangan ngebacot yg tak sesuai dengan fakta Like Reply $B 2 \cdot 8 \mathrm{hrs}$

16 Rizki Maulana ajaran untuk membunuh? tinggal d indonesia kan gio? tetangga islam mu sudh brusha membunuh kamu kah? Like - Reply 14 - 8 hrs

Dizn Cavallera Cavallera Kalo islam jahat,lu udah modar di indonesia sini di bantai islam jangan asal nguap aja lu koplok ngomong tuh.

Like Reply 13.8 hrs

2. Wahyu Arif Susilo situ ajaran apa ?? sesat yah? Like - Reply- 8 hrs

Wahyu Arif Susilo 1 lagi kamu adja gampang dibodohin.jgn lasng percaya yang namanya berita di cari dlu akarnya mas brew Like Reply ib1-8 hrs

Amir Kuro udah lah, jangan terpancing sama omongan seorang idiot Like Reply $13-8$ hrs

(3) Hermanto Otak lu kali yg kacau balau.., haha (:) Like Reply $B 2-8$ hrs

37. Gio Matthijs Bunuh orang-orang kafir yang ada di sekitarmu* (QS 


\section{Appendix 2. Screenshot of DRAH's interaction with other participants}

Denny Rieka Asyifatu Haifa Mantap lah...

Prancis membuat undang2 larangan berhijab....

Dulu karikatur prancis membuat komik yg menjelekan nabi muhammad. Ini hasilnya, ayo negara mana lagi yg menghina...

Like - Reply - $23 \cdot 11$ his

A Hide 31 Replies

Q. Jason Ibrahim Berarti teroris ISIS itu islam dong....hahaha Like Reply 16 - 11 hrs

1. FA Badila Mas berarti emang bener sedikit disindir dan dikritik emosi? Bunuh orang? Aneh banget ajaran keyakinannya lol Like Reply $B 2 \cdot 11$ hrs

F. Deni Kristian Nainggolan Bro.. di prancis itu orang bebas bereksprisi dan mengeluarkan pendapat. Like-Reply 13 - 10 hrs

8enny Rieka Asyifatu Haifa Jason \# silahkan anda percayai. Dan gak ngaruh dengan nama islam, ingat islam itu banyak bu golongannya. Sama dengan kristen yg lebih dari 100 golongan.....hahahaha Like Reply $B 1 \cdot 10 \mathrm{hrs}$

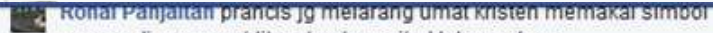
agama di ruang publik,gak ada yg ribut tuh umatnya. Like - Reply $B_{2} \cdot 10 \mathrm{hrs}$

Penny Rieka Asyifatu Haifa FA \# apa bedanya dengan agama lo yg membunuh ribuan orang. Perang salib, di irak.....hahaha...itu yg agama yg lol, bunuh orang dari balita sampai manula Like Reply - 10 hrs

11. Erik Sar Kristen pun kena larangan di francis tp $g k$ ada tuhh yg marah sampe buat teror segala

Like-Reply-B2-10 hrs

Denny Rieka Asyifatu Haifa Ronal \# simbol agama ada gak d dalam bible, injil / alkitab gitu...

Like Reply $11.10 \mathrm{hrs}$

Denny Rieka Asyifatu Haifa Erik \# larangan apa? Like - Reply - $10 \mathrm{hrs}$

Ibnu Setyo Hartiyasno Mas denny. aqmau tanya di alquran emang ada ayat yg menyuruh membunuh orang yah?

Like Reply 31 - $10 \mathrm{hrs}$ - Edited

9. Suryadi Adrian Terus pantes di bom gitu???? Like - Reply - 10 hrs

19. Suryadi Adrian Ohhh relegion of peace ya...

Like Reply 10 hrs

I. Suryadi Adrian Sip... Like - Reply - 10 hrs

- Bambang Sujat Moko Jason Ibrahim

Klu ini teroris juga donk.

https:I/Www.facebook com/JAYALAH.INDONESIAKU/photos /a.531286596918983.1073741826.117997638247883 $1870095229704783 / 7$ tve $=18$ theater 


\section{Copyrights}

Copyright for this article is retained by the author(s), with first publication rights granted to the journal.

This is an open-access article distributed under the terms and conditions of the Creative Commons Attribution license (http://creativecommons.org/licenses/by/4.0/). 